\title{
Composing a Better World
}

\author{
Andrea Church* \\ Grant MacEwan University, Canada
}

\begin{abstract}
This article is a study of the musical composition, We Arrived Safely Because We Sailed Too Close to Shore, by Ryan Sims. Some of the research techniques are discussed, as well as the inspiration for the piece, the tools he used, and the technical details of production. Ryan did not learn to read music until he attended Grant MacEwan University's music program - a year is a short time to transition from learning how to read and write music to being able to compose a multi-instrument piece. He was inspired by a journey and felt that it reflected his own life's path. Ryan's piece is only the beginning for his career. He finds inspiration in everything and brings that talent to his work.
\end{abstract}

\section{The Composer}

As children, we dream about fame, fortune, and notoriety. Many of us envision being stars and playing to a crowd of thousands; not many of us dream of composing that music. Neither did Ryan Sims. It wasn't until age sixteen that Ryan learned to play the guitar; on a twelve-string his dad had tucked away in a back closet. Even then music was a hobby, not a career. Ryan completed a Bachelor of Political

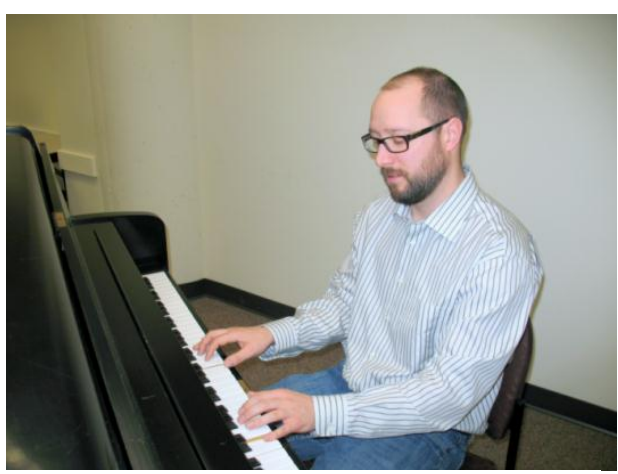

Figure 1: Composer Ryan Sims 
Sciences at Saskatoon, Saskatchewan's Eston College and spent years working a variety of jobs, one of which was teaching guitar lessons. He wrote songs, but did not learn to write music until his first year in the Music Program at Grant MacEwan University in Edmonton, Alberta, Canada. A skill Ryan says opened a new world for him. He could finally express the sounds he heard in his head.

\section{The Project}

In support of student creativity and imagination, each spring the Music Program hosts several live performance concerts designed to showcase student work. The Composers' Concert provides a musical forum where students who study music composition are able to present, play, and/or conduct their musical pieces on stage at the university's performing arts theatre. As part of a Capstone Project in his final year, Ryan Sims composed and conducted his original musical piece: We Arrived Safely Because $W$ S Sailed Too Close to Shore. The notes within his music tell a story; a different version for each person who listens. For example, someone may envision woodland fairies dancing in a sunny clearing, or someone else may imagine rain and high winds. As for Ryan, when he listens to his piece, he visualizes a sailboat skimming along the coast, hit by a storm and riding out the wild winds and torrential waves. But how did Ryan approach his composition? From where did he draw his inspiration to write these musical notes?

\section{The Composition}

The process of composing an original piece of music requires concentration, inner focus, musical knowledge, creativity, and persistence. The act of composing is complex; one only needs to read a musical score to appreciate the in-depth first-hand knowledge that a composer requires to be successful at creating music. Such is the case regarding Ryan's musical piece. Five instruments can be heard within his composition: piano, flute, marimba, glockenspiel, and bassoon. In order for him to integrate and enmesh the intricate sounds that comprise his piece, Ryan needed to know what effect each

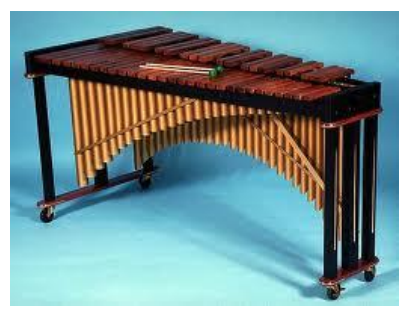

Figure 2: Marimba instrument created. Knowing the different sounds, ranges, and limitations of the instruments allowed Ryan to carefully select them as part of his orchestral arrangement. Such knowledge informed his choices and ensured that they were the right instruments that would accurately produce the sounds he sought to express within his piece. For example, "the modern 
marimba (Figure 2) has wooden bars laid out in two rows like the keyboard on a piano. These bars are struck with medium-hard mallets or sticks often made of wound yarn to produce the sound. The bars are usually made of rosewood, and the shorter and narrower the bar is the higher the pitch of the note will be" (Associated Board of the Royal Schools of Music, 2006). "The Glockenspiel - Figure 3, (which literally means 'playing bells') has tuned metal bars, usually made of steel, arranged in two rows like the black and white notes on a piano keyboard. These metal bars are hit by mallets or beaters, which have playing ends made of hard materials such as wood, nylon, plastic, or

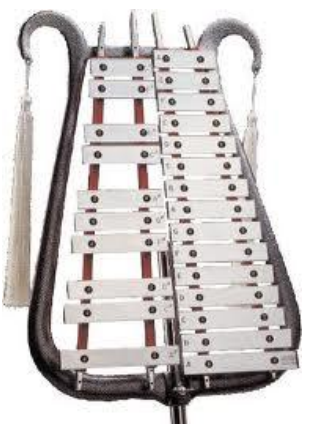

Figure 3: Glockenspiel rubber. The sound produced is bell-like and high-pitched. This is the kind of instrument commonly found in the Western classical orchestra" (Associate Board of the Royal Schools of Music, 2006).

Instrument range and technical musicality are just two areas of knowledge that are applied by a composer when creating a piece. Timing is another. A key signature refers to the key that the piece is played in, and can change with each staff. "In musical notation, the musical staff or stave is a set of five horizontal lines on which musical note symbols are placed to indicate pitch and time. The staff is read left to right and the higher a position on the staff, the higher the pitch of the note to be played. If a note appears above or below the 5 lines, ledger lines are used to indicate the exact note. The musical staff on its own does not help you to represent any specific notes; that is without a musical clef. The two main clefs are Treble clef and Bass clef - if these are combined it is called a grand staff. When reading music you will have a Clef Type, a Key Signature and a Time Signature" (Macdonald, 2011).

The time signature is placed at the beginning of the music AFTER the key

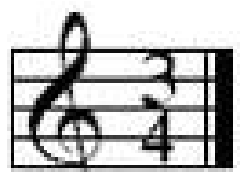

Figure 4: Key and Timing Signatures signature, "The upper figure [number 3] tells us how many beats are in each bar, and the lower figure [number 4] tells us what kind of a note is to get one beat" (Wharram, 1969) (Figure 4). This refers to "simple time". We Arrived Safely Because We Sailed Too Close to Shore, changes from twelve-eight time to three-quarter time. The tempo builds, becoming frantic, and then calms and returns to its beginning. Ryan describes it as a mirror for his schooling. Challenged with significant demands from life, work, and relationships while going to school, Ryan believes that life experiences can feel like a storm, but then you finish, and life rolls on in much the same way. "Everything has irrevocably changed, but is still the same." It is about a change in 
perspective, which also influences the inspiration and research that supports his creative work.

\section{Inspirational Research}

Ryan describes his style as a folksy, jazzy, acoustic blend of sounds. His inspiration comes from many sources, but this piece stemmed from a story he heard on the "Q" radio show on CBC (740) which is broadcast throughout Canada and parts of the United States. A band called "Tennis," consisting of a husband and wife team with a background (and degrees) in philosophy decided to buy a boat and sail around the world. Limited space meant that they couldn't bring musical instruments with them, but while they were in the Florida Keys they experienced the sounds of some amazing music. Ryan describes the music that these two travellers heard as a blend of 50s rock music and surfer rock. While the husband and wife team were in the Florida Keys, a local band inspired them so much that as they continued their voyage around the world, they created an album note by note without the use of musical instruments. When listening to the interview of these two travellers, Ryan learned that because they were inexperienced sailors, they stayed close to shore throughout their journey. "People going for their dreams are my inspiration," Ryan reflects, "I write without knowing what the end will be."

The title of his piece was also inspired by Sir Francis Drake's Prayer from 1577: Disturb us Lord, when we are too pleased with ourselves, when our dreams have come true because we dreamed too little, when we arrived safely because we sailed too close to the shore..." (Berry, 2011).

However, being inspired to create a musical piece is only the first step to composing. Hard work and persistence, accompanied by technology all played roles in the successful creation of Ryan's piece. He used a program called Logic Pro to write his piece. Each instrument's sounds were programmed into Logic Pro's memory, and every note was handpicked. "Sound is a colour palette of feeling," explained Ryan, "I write what is rolling around in my head." One-on-one consults with Allen Gilliland, the Head of Composition in the Music Program at Grant MacEwan University, helped polish the piece to its finished form.

Ryan's research approach to his composition combined with his creative inspiration is a common approach that composers use when creating a musical piece. Similar to creating a chemical formula for a new drug, many versions of Ryan's musical score were attempted and discarded before the desired blend of notes and sounds were achieved, resulting in his original piece: We Arrived Safely Because We Sailed Too Close to Shore.

ECJ Volume 1, No. 1, 2011 


\section{Music and Conservation}

The connection between music and conservation is an important one. Many musical composers are inspired by the sounds of nature, which in turn also inspire others to understand and appreciate nature's power and vulnerability. For example, Vivaldi's composition of the Four Seasons resonates with the sounds of nature; its gentleness, its playfulness, and its fury (Everett, 1996).

While a composer will never know all the ways in which his or her musical piece inspires others, it is rewarding and surprising to learn about some of them. When he wrote his piece, Ryan had no idea that it would be showcased in Earth Common Journal. $\mathrm{He}$ is excited and impressed by the existence of an undergraduate journal devoted to sustainability, conservation, and global warming. "I wouldn't call myself an activist," he says, "but a step on the road to sustainability is important to me." He believes that people are basically reasonable, and if they are given easy, convenient ways to adapt their lifestyles to be more environmentally friendly, they will do it. Ryan explains that he has started taking small steps in improving his own lifestyle by recycling and using less water.

Ryan Sims' original musical piece can be heard by clicking on the "Musical Composition" link located to the right of the article's name in the Table of Contents list of Earth Common Journal.

* Author: Andrea Church is a Features Editor for the Earth Common Journal, and is currently completing her fourth year in the Bachelor of Applied Communications in Professional Writing degree program at Grant MacEwan University, Canada.

ECJ Volume 1, No. 1, 2011 


\section{References}

Berry, S. (n.d.). Grace - Fresh Vital Worship. Retrieved April 30, 2011, from Prayer of Sir Francis Drake: http://www.freshworship.org/node/248

Everett, P. (1996). Vivaldi: The Four Seasons and Other Concertos. Cambridge, U.K.: Cambridge University Press.

Shane McDonald. (n.d.). Music Section of Shane McDonald. Retrieved April 30, 2011, from Learning to Read Key and Time Signatures: Music References: http://www.shanemcdonald.org/music/learn-to-read-notes.html

Wharram, B. (1969). Elementary Rudiments of Music. Oakville, Ontario: The Frederick Harris Music Co. Limited. 